\title{
Remedies to Challenge Arbitral Awards in Pakistan
}

\author{
Sohaib Mukhtar ${ }^{1 *} \&$ Shafqat Mahmood Khan Mastoi ${ }^{2}$ \\ ${ }^{1}$ Faculty of Law, National University of Malaysia, Selangor, Malaysia \\ ${ }^{2}$ Head of Legal, VimpelCom, Amsterdam, Netherlands \\ *Sohaib Mukhtar, E-mail: sohaibmukhtar@gmail.com
}

\begin{abstract}
Available remedies to challenge arbitral awards in Pakistan are modification, remission, annulment and revocation of recognition and enforcement. Arbitration is a method through which disputing parties resolve their disputes outside the Court by avoiding technicalities of procedural law. If there is irregularity regarding process and procedure of arbitral tribunal, parties to an arbitration agreement may apply against it in the Court. Arbitrator files an arbitral award in the Court after completion of arbitral proceedings. If arbitral award is domestic and comes under ambit of Civil Court, arbitrator files arbitral award there but in case of foreign arbitral award, parties to arbitration agreement are required to file arbitral award with arbitration agreement and in case if arbitral award and arbitration agreement are not in official language of Pakistan, translation in official language is required to be submitted before High Court for implementation of arbitral award in Pakistan. Aggrieved party to arbitration agreement may challenge arbitral award before the Court for modification under section 15, for remission under section 16 and for setting aside under section 30 of the Arbitration Act 1940. Recognition and enforcement of an arbitral award may be challenged under article 5 of the New York Convention 1958. The UNCITRAL Model Law 1985 and other relevant International Conventions are not applicable in Pakistan thus aggrieved party may not avail grounds mentioned in these Statutes for modification, remission, setting aside and revocation. Pakistan is an Islamic country hence no award can be implemented in Pakistan if it is against injunctions of Islam under the light of Holy Quran and Sunnah of Prophet Muhammad which comes under ambit of public policy which is one of the grounds for revocation of recognition and enforcement of an arbitral award in Pakistan.
\end{abstract}

\section{Keywords}

arbitration, modification, remission, setting aside, un-enforcement, public policy

\section{Introduction}

Arbitration is resolution of dispute between contracting parties of arbitration agreement by one or more arbitrators and their decision is called an arbitral award. Arbitrator pronounces his decision, signs arbitral award and files it before the Court for its implementation. Domestic arbitral award is required to be submitted in Civil Court and international arbitral award is required to be submitted before High Court for its recognition and implementation in Pakistan. 
The Court may modify arbitral award if (i) there is an error (ii) typographical mistake (iii) similar nature error but the Court cannot start modification process if it affects subject matter of arbitral award and in this case, the Court is required to send back arbitral award to an arbitrator for reconsideration. Concepts of additional award and interpretation of award are given under the UNCITRAL Model Law 1985 but it is not applicable in Pakistan. Pakistan has dualism system which requires an act of the Parliament or an Ordinance of President to implement International Treaty at its soil. Aggrieved party may avail modification grounds mentioned under section 15 of the Arbitration Act 1940 but cannot avail grounds mentioned under article 33 of the UNCITRAL Model Law 1985 in Pakistan.

An aggrieved party to an arbitral award may apply for setting aside an arbitral award in Pakistan before the Court within 30 days as per article 158 of the Limitation Act 1908. There are 6 grounds prescribed under section 30 of the Arbitration Act 1940 for setting aside an arbitral award in Pakistan, apart from this, there are 6 grounds prescribed under article 34 of the UNCITRAL Model Law 1985 and 5 grounds under article 52 of the International Center for Settlement of Investment Disputes (ICSID) Convention 1965 for setting aside an arbitral award but they are not applicable in Pakistan. It is highly recommended that government of Pakistan should implement the UNCITRAL Model Law 1985 and related International Statutes in Pakistan for benefits of people who want to resolve their disputes through arbitration and want implementation of their arbitral awards in Pakistan.

The New York Convention 1958 is applicable in Pakistan through the Recognition and Enforcement Act 2011; it provides 7 grounds for revocation of foreign arbitral awards' enforcement in Pakistan. When award is annulled by the Court then decision of an arbitrator cannot be enforced in any part of the world. When an arbitral award becomes null and void, other party may apply in the Court for its refusal to enforce or the Court may itself check its validity.

If parties to an arbitration agreement do not challenge an arbitral award within prescribed time, it would then be considered as they have waived their right to challenge an arbitral award. Limitation is the most important thing in challenge, law does not help a person who sleeps on his right, challenging an arbitral award is a right but it has limited time thus aggrieved party is required to challenge an arbitral award within specified time limit. Limitation for parties to challenge arbitral award in Pakistan is 30 days to make a request in writing for annulment of an arbitral award or for revocation of its enforcement before the Court. Challenging time for all types of civil decisions in Pakistan is 90 days under section 96 of the Code of Civil Procedure 1908, it is highly recommended that government of Pakistan should amend article 158 of the Limitation Act 1908 and enhance time limit for challenging arbitral award from 30 to 90 days as well as amend the Arbitration Act 1940 as per customs and usages of Pakistani society, relevant international statutes and in accordance with injunctions of Islam laid down in Holy Quran and Sunnah of Prophet Muhammad to make better structure of arbitration law in Pakistan. 


\section{Modification of Arbitral Award}

First remedy which parties to an arbitration agreement may avail in Pakistan is modification of an arbitral award. The Court on request of parties or on its own motion may modify an arbitral award and correct any clerical mistake arisen out of typographical error. Modification includes (i) removal of things which were not referred to an arbitrator for consideration and resolution, (ii) removal of clerical mistake, (iii) removal of an obvious error. The Court is empowered to modify an arbitral award in Pakistan under section 15 of the Arbitration Act 1940 if an arbitral award consists any clerical mistake, computation error or any similar kind of error.

The Court in Pakistan may modify an arbitral award when it contains clerical mistake on the face of it or any kind of error arisen out of accidental slip or omission. The Court may modify an arbitral award through an order without sending back award to an arbitrator (1940). Peshawar High Court held in a case between Syed Faqir Shah v Inayatullah Khan that it is generally known that the Court should go towards acceptance rather than rejection of an arbitral award but it has powers of modification, remission and setting aside an arbitral award under sections 15, 16 and 30 of the Arbitration Act 1940 and under section 151 of the Code of Civil Procedure 1908 (2013).

Section 15 of the Arbitration Act 1940 empowers the Court to modify an arbitral award in Pakistan and section 13 of the Arbitration Act 1940 empowers an arbitrator and an umpire to correct any clerical mistake or an error arisen out of accidental slip or omission. The Court and arbitrator have limited powers to modify an arbitral award without affecting subject matter of an arbitral award. Lahore High Court held in the case between Muhammad Saleem $v$ SAADAT Enterprises that arbitrator does not have power to interpret an arbitral award in a way to replace his own views (2009).

Sindh High Court held in a case between Al-Abdullah Contractors Private Limited v Pakistan Water and Development Authority that arbitrator is a judge in all referred disputing matters between contracting parties of an arbitration agreement, it is not good for the Court to scrutinize award just for purpose of discovering an error in an arbitral award. An arbitral award is final and binding upon contracting parties (2008).

One more case which demonstrates clear idea about modification of an arbitral award by the Court in Pakistan is case of Sindh High Court between Razo Private Limited v Pakistan Steel Mills Corporation Private Limited, the Court held that while examining validity of an arbitral award, the Court is not considered being Court of Appeal. The Court hears objections against arbitral award and the Court cannot take evidence before it which was produced before an arbitrator and modification can only be exercised by the Court if an error or an infirmity in an arbitral award is clear and constant which renders an arbitral award invalid (2009).

One more relevant case is of Islamabad High Court between National Highway Authority v MESSRS HAKAS Private Limited, the Court held that it is not allowed for the Court to enter merits of the case which was referred to an arbitrator. Modification does not mean changing of an arbitrator's decision and if modification changes decision of an arbitrator, such modification is liable to be set aside (2011). 
The UNCITRAL Model Law 1985 and the ICSID Convention 1965 contain sufficient grounds of modification, remission, setting aside and un-enforcement of an arbitral award but they are not applicable in Pakistan, it is highly recommended that these Statutes and other relevant Treaties should be implemented in Pakistan, so aggrieved party may avail more grounds for modification, remission, setting aside and un-enforcement of an arbitral award in Pakistan.

It is sufficient to elaborate grounds of modification mentioned under the UNCTIRAL Model Law 1985. Article 33 of the UNCITRAL Model Law 1985 empowers arbitral tribunal to modify an arbitral award and to give an interpretation of an arbitral award of any specific point which is required to be interpreted. Arbitral tribunal is required to give an interpretation of an arbitral award within 30 days and that interpretation would be considered part of an initial arbitral award. Parties to an arbitration agreement may ask arbitral tribunal to issue an additional award if referred issues are omitted from arbitral award. Arbitral tribunal is required to make an additional award within 60 days and that additional decision of an arbitrator would become part of an initial award (IKerr, 1985).

Article 33 of the UNCITRAL Model Law 1985 states that after declaration of an arbitral award within 30 days, any party to an arbitration agreement after giving notice to other party may request arbitral tribunal for correction of computation error in an arbitral award in case if there is any clerical error or typographical mistake or obvious error of similar nature. Computation error is defined by Harare High Court, Zimbabwe in a case between Zimbabwe Electricity Supply Commission v Genius Joel MAPOSA, the Court held that arbitral tribunal made an error based on facts in calculation of back pay, the Court held that error in this case is of computation under article 33 of the UNCITRAL Model Law 1985 (1998).

Error of a similar nature is defined by Singapore High Court in a case between VANOL Far East Marketing Private Limited v HIN Leong Trading Private Limited, the Court held that mistakes made by contracting parties reflected in the decision of an arbitrator. One of the parties to an agreement of arbitration mistakenly forgotten to include certain expenses of costs in the bill, such kind of mistakes are considered errors (1996).

Limitation for application of modification is 30 days under the UNCITRAL Model Law 1985, thereafter arbitral tribunal is required to issue interpretation of an arbitral award within 30 days and additional award within 60 days, if applied for by parties to an agreement of arbitration. It is not mandatory upon contracting parties to apply for correction of an arbitral award, the Court or arbitral tribunal may on its own motion correct any error of an arbitral award within 30 days after declaration of decision by arbitrator (Redfern, 2004).

Application for modification of an arbitral award in Pakistan is required to be made within 30 days and there is no compulsory requirement on the Court to modify an arbitral award within 30 days. Section 15 of the Arbitration Act 1940 states that the Court has jurisdiction to correct an arbitral award through its order when it seems that there is something mentioned in an arbitral award which was not referred to an arbitrator for arbitration and arbitrator mistakenly added non-referred issues in an arbitral award. The Published by SCHOLINK INC. 
Court can only modify an arbitral award if other part of award does not effect from modification (Won, 2013).

It is pertinent to mention here that article 47 (d) of the Constitution of Pakistan 1973 dealing with Principles of Policy requires Federal Government of Pakistan to ensure inexpensive and expeditious justice, it is highly recommended that Government of Pakistan should strengthen arbitration system of Pakistan by taking steps of suggested amendments in the Arbitration Act 1940, as per customs and usages of Pakistani society under the light of International Treaties and as per injunctions laid down in Holy Quran and Sunnah of Prophet Muhammad 能.

\section{Remission of Arbitral Award}

Second remedy which parties to an arbitration agreement may avail in Pakistan is remission of an arbitral award. If an arbitral award does not contain details referred to an arbitrator for arbitration and does not fall under one of the grounds of modification prescribed in sections 13 and 15 of the Arbitration Act 1940, aggrieved party may apply before the Court for remission of an arbitral award. When there is any kind of error which cannot be modified without affecting arbitral award, the Court is required to remit arbitral award to an arbitrator on application of interested party. Similarly, if arbitrator did not consider all issues referred to him in a reference, the Court would resend matter to an arbitrator for reconsideration (1940).

If arbitral award falls under grounds of modification, the Court would modify arbitral award on request of parties or on its own motion. Remedy of remission can only be obtained when remedy of modification cannot be obtained. Remedy of modification and remission are not mentioned in the New York Convention 1958 and in the Recognition and Enforcement Act 2011 because both statutes deal with recognition and enforcement of arbitral awards made outside Pakistan and they do not deal with arbitration procedure.

Section 16 of the Arbitration Act 1940 states that the Court may resend matter to an arbitrator (i) when arbitral award has not determined all matters referred to an arbitrator for resolution, (ii) when arbitral award consists matter which was not referred to an arbitrator for consideration, (iii) when the Court cannot modify an arbitral award because it would affect other part of arbitral award, (iv) when arbitral award is incapable of execution because it is indefinite, (v) when reservation upon legality of an arbitral award is obvious (1940).

When the Court resends matter to an arbitrator, it gives certain time for subsequent award, failing to issue subsequent award within specified time would render arbitral award invalid and will have no effect. Sindh High Court held in a case between Abdullah Contractors $v$ Water and Power Development Authority that the Court has supervisory jurisdiction upon arbitral award and not appellate jurisdiction. The Court in supervisory jurisdiction examines whether parties have given equal opportunities before arbitrator or not and if award is not based upon evidence as no evidence was produced before arbitrator disclosed by examining record, the Court would annul arbitral award and Published by SCHOLINK INC. 
resend same to an arbitrator and ask him to reconsider matter and give equal opportunities to contracting parties again and give decision based upon solid evidence (2006).

The Court may also resend award (i) if decision of an arbitrator or an umpire is ambiguous and not clear, (ii) if fundamental issues between parties are not addressed, (iii) if there are additional things mentioned in an arbitral award which were not referred to an arbitrator for arbitration and that thing cannot be set apart from arbitral award without affecting other part of arbitral award. Moreover, when arbitrator does not file arbitral award in the Court within 4 months and an umpire within 2 months in Pakistan, the Court would remit an arbitral award because decision of an arbitrator submitted in the Court after expiration of prescribed time renders an arbitral award invalid (1940).

Sindh High Court held in a case between Falcon Enterprises v National Refinery Limited that the Court acts in supervisory jurisdiction and examines whether arbitral award made by arbitrator is based upon material placed before him and whether parties to arbitration agreement had given equal opportunity to prove their opinion. If arbitrator does not decide case upon solid evidence, the Court would declare an arbitral award void and resend it to an arbitrator for reconsideration (2006).

Similarly, Lahore High Court held in a case between S.M.I Brothers v Municipal Committee Murree that the Court has limited jurisdiction while examining validity of an arbitral award. If there is any clear error or disregard of law during arbitral proceedings, the Court would set aside an arbitral award and resend matter to an arbitrator (2003).

Another similar case is a case between Water and Power Development Authority v MESSRS Ice Pak International Consulting Engineers of Pakistan, Lahore High Court held that arbitrator is bound to act on terms agreed upon by contracting parties, if arbitrator fails to fulfill implementation of arbitration agreement between contracting parties, it would be considered an error on the face of it which will nullify arbitration proceedings (2003).

One more case gives more clear picture is the decision of Sindh High Court in a case between ADAMJEE Construction Company Limited v Islamic Republic of Pakistan, the Court held that before making award rule of the Court, it is obligation of the Court to see whether there is any cause exists to resend award to an arbitrator and to remove clerical mistake or typographical error. If aggrieved party is not successful to file objection within specified time, it would not be precluded that the Court becomes FUNCTUS Officio. It is duty of the Court as a supervisory body to see whether there is any kind of irregularity in arbitral award or whether there is any error or omission. It is also duty of the Court to see whether arbitral tribunal worked under arbitration agreement and under special law related to matter or not and after watching all aspects of arbitral award thoroughly, the Court is required to make an order for making an arbitral award rule of the Court for execution. The Court should thoroughly watch (i) whether there is any ground for modification or not, (ii) whether there is any matter to remit arbitral award left by arbitrator or not, (iii) whether arbitration agreement is valid and arbitral tribunal acted as per arbitration agreement and law of the land or not (2003). 
One more relevant case between Zakaullah Khan $v$ Government of Pakistan, the Court held that an arbitral award is an outcome of arbitration proceedings conducted by one or more arbitrators chosen by parties. Purpose behind arbitration proceedings is decision in lesser time than through litigation in the Court. Arbitrators are not bound to follow rules of Qanun-E-Shahadat Order 1984. The Court acts as supervisory body for modification, remission and setting aside an arbitral award or for making arbitral award rule of the Court and it does not act as an appellate body under the Code of Civil Procedure 1908.

As explained earlier, the UNCITRAL Model Law 1985 is not applicable in Pakistan, it is required to be implemented due to its significance in the area. The UNCITRAL Model Law 1985 does not deal separately with issue of remission. Article 33 of the UNCITRAL Model Law 1985 states that arbitral tribunal on its own or on the request of parties may modify arbitral award within 30 days and issue interpretation of an award within 30 days and issue additional award within 60 days (Hunter, 1985).

It is pertinent to mention an interesting concept of Inter PETITA Award under England Arbitration Act 1996. Section 68 of the English Arbitration Act 1996 states that if there is any irregularity which effects arbitral tribunal or arbitral award or arbitral proceedings and that irregularity is raised by an aggrieved party before the Court. The Court is required to resend matter to arbitral tribunal whole or in part. Word used for remission Inter PETITA Award means: arbitrator has not resolved all issues referred to him in a reference hence arbitral award is incomplete and the Court is required to resend matter to an arbitrator for reconsideration. If there is an additional thing in an arbitral award, the Court can modify arbitral award before considering remedy of remission but if arbitral award cannot be modified, the Court is required to resend matter to an arbitrator for modification in a way that subject matter of arbitral award must not be disturbed by modification (Shackleton, 1997).

\section{Setting Aside Arbitral Award}

Third remedy which parties to an arbitration agreement may avail in Pakistan is setting aside an arbitral award. When an aggrieved party feels that he has sufficient grounds to believe that an arbitral award is not valid, he may apply for setting aside an arbitral award before the Court. There are certain grounds mentioned under section 30 of the Arbitration Act 1940 for setting aside an arbitral award. An aggrieved party is required to challenge an arbitral award for setting it aside within 30 days in Pakistan under article 158 of the Limitation Act 1908. An aggrieved party to an arbitral award can challenge an arbitral award for setting it aside on prescribed grounds mentioned in section 30 of the Arbitration Act 1940. Section 30 of the Arbitration Act 1940 states that on request of parties, the Court can annul arbitral award (i) if arbitrator misconducts himself, (ii) if arbitrator misconducts with arbitration proceedings, (iii) if arbitral award has been improperly procured, (iv) if arbitral award is made after order of the Court superseding arbitration, (v) if arbitral award has superseded arbitration, (vi) if arbitral award is otherwise invalid (1940). 
Burden of proof in case of arbitral award annulment is upon applicant who seeks remedy of annulment before the Court. Sindh High Court held in a case between ENGRO Fertilizers Limited v Federation of Pakistan that burden of proof for proving that arbitral award is not based upon findings and upon produced evidence before arbitrator is upon an applicant who seeks remedy of setting aside an arbitral award. Applicant must prove serious irregularity on the face of it about procedure of arbitral tribunal and that irregularity cannot be ignored otherwise it would cause serious injustice (Mukhtar \& Mastoi, 2017).

Azad Kashmir High Court held in a case between Communication and Works Department $v$ Messrs Design and Engineering System that an arbitral tribunal has exclusive jurisdiction under arbitration agreement to decide issues between contracting parties, the Court acts as supervisory body upon arbitral tribunal and not as an appellate body and arbitral tribunal's decision is not allowed to be challenged except on prescribed grounds mentioned under the Arbitration Act 1940 (2013).

Presumption of correctness is attached with arbitral award. It cannot be disturbed merely on technical reasons. The Court cannot interfere in merits of arbitral award. Islamabad High Court held in a case between Oil and Gas Development Company Limited v MESSRS Marathon Construction Company that when arbitrator frames issues during proceedings of arbitration, the Court would not necessarily frame issues again. Presumption of correctness is attached with arbitral award during submission in the Court, only grounds for setting aside are those which are given by law. An arbitral award cannot be disturbed just at whims of some party, when merits of arbitral award is not affected, it cannot be disturbed on mere technical reasons (2013).

Section 11 of the Contract Act 1872 states that all persons are competent to enter agreement except minor, lunatic and disqualified person by law (1872). When party to an agreement of arbitration does not have capacity to enter contract, agreement is void, arbitral tribunal made upon invalid agreement is void and arbitral award comes out after arbitration proceedings is void. If parties to arbitration agreement do not have physical or mental capability and capacity required by law to enter an arbitration agreement, agreement is void and arbitral tribunal is not allowed to act upon void contract (2010).

An arbitral award is also void when arbitrator excesses his powers. An arbitrator has powers determined by parties given in an arbitration agreement but if parties have not decided it, the Arbitration Act 1940 gives certain powers to an arbitrator in Pakistan. When arbitrator excesses his powers, aggrieved party may apply in the Court for setting aside an arbitral award (1940).

An arbitral award may also become void if it is improperly procured or if subject matter of arbitration proceedings is not allowed to be arbitrated, e.g., arbitration process runs in civil nature cases between contracting parties and not in criminal matters, disputing parties may avail method of mediation and other modes of Alternate Dispute Resolution for resolving their disputes outside the Court in criminal matters (Mukhtar, 2016). 
It is pertinent to mention here that irregularity and jurisdiction of arbitrator must be raised during arbitration proceedings and not at the time enforcement of arbitral award. Lahore High Court held in a case between Muhammad Nadeem v Additional District Judge, Bhakkar that there was no objection raised upon jurisdiction of an arbitrator during proceedings of an arbitration, when an arbitral award came out of arbitration proceedings, parties objected upon jurisdiction of an arbitrator, this kind of objection is not allowed (2012).

If constitution of arbitral tribunal is not in conformity with arbitration agreement of contracting parties or if arbitrator does not follow rules of due process and parties are not given equal opportunities before arbitrator to defend their contention. General rule is that the Court goes in favor of acceptance and does not disturb arbitral award except in gross miscarriage situation. Azad Kashmir High Court held in a case between Communication and Works Department v MESSRS Design and Engineering System that High Court does not sit upon arbitral award as an Appellate Court nor as arbitral tribunal. If findings of an arbitrator are based upon documentary evidence and there is no misreading or non-reading of an evidence, the Court will not disturb arbitral award. The Court would always go in favor of noninterference rather than interference in findings of an arbitrator based upon documentary evidence. The Court can only interfere in arbitral award if there is gross miscarriage of justice (2013).

Another case which provides us clear idea about challenging grounds in Pakistan is the case of Lahore High Court between Muhammad Nadeem v Additional District Judge Bhakkar, the Court held that when arbitral award is in accordance with provisions of the Arbitration Act 1940, it cannot be set aside. An arbitral award can only be set aside (i) if arbitral award is improperly procured, (ii) if arbitral award is made after decision of the Court staying proceedings, (iii) if arbitral award is superseding the Court proceedings, (iv) if arbitrator misconducts himself, (v) if arbitrator misconducts with arbitration proceedings (2012).

One more case which is decided by Peshawar High Court between Government of N.W.F.P. $v$ Jan Construction Company, the Court straightaway announced arbitral award rule of the Court without commenting upon validity of an arbitral award. Peshawar High Court held that the Court is duty bound under law of the land to consider all questions of law and fact, the Court is empowered to deny decision of an arbitrator to be made rule of the Court as well as it has jurisdiction under section 16 of the Arbitration Act 1940 to resend arbitral award to an arbitrator if there are certain deficiencies (2012).

If arbitrator holds an inquiry in arbitration proceedings, takes sufficient documentary evidence, hears both sides of an arbitration agreement, decides issue and submits it in the Court with authentication of both parties in accordance with provisions of the Arbitration Act 1940, parties to an arbitration agreement cannot take back their statements made before an arbitrator and cannot state anything different of what they have said earlier before an arbitrator and law of Estoppel would apply upon arbitral award and parties to arbitration agreement (1984).

Governing law of arbitration agreement is law of country where agreement is solemnized except if otherwise expressly decided by contracting parties in a contract. Supreme Court of Pakistan held in a Published by SCHOLINK INC. 
case between Maulana Abdul Haque Baloch v Government of Baluchistan that when foreign company or foreign national enters an agreement, it will be governed by national laws of country unless contrary is decided by parties in a contract. The Court follows procedural laws of the land as in Pakistan, arbitration is a civil matter which is procedurally governed by the Code of Civil Procedure 1908 (2013).

It is pertinent to mentioned here grounds of setting aside prescribed under article 34 of the UNCITRAL Model Law 1985 and under article 52 of the ICSID Convention 1965. Article 34 of the UNCITRAL Model Law 1985 states that an aggrieved party of arbitration proceedings may challenge an arbitral award for setting it aside at place of arbitration (i) if parties to an arbitration agreement do not have capacity under law of the land to enter an arbitration agreement, (ii) if arbitration agreement is void, (iii) if parties do not have notice about appointment of arbitrator, (iv) if issue is not allowed to be arbitrated, (v) if composition of arbitral tribunal is not in accordance with arbitration agreement or relevant law of the land (vi) if arbitral award is in conflict with public policy (1985).

Article 52 of the ICSID Convention 1965 states grounds for setting aside an arbitral award. It states that aggrieved party to arbitration proceedings may request for annulment of an arbitral award (i) if arbitral tribunal is not properly constituted as agreed upon between contracting parties, (ii) if arbitral tribunal has exceeded from its powers, (iii) if there was a corruption on part of arbitral tribunal members, (iv) if fundamental rules of procedure were not followed, (v) if arbitral award does not disclose reasons (1965). The UNCITRAL Model Law 1985 and the ICSID Convention 1965 are not applicable in Pakistan, it is highly recommended that these International Statutes and other relevant statutes should be made part of domestic law of Pakistan or these provisions should be imbedded in Arbitration Act 1940, so that aggrieved party may avail more grounds for setting aside an arbitral award in Pakistan.

\section{Un-Enforcement of Arbitral Award}

Last remedy which parties to an arbitration agreement may avail in Pakistan is annulment of recognition and enforcement of an arbitral award in Pakistan. In case of foreign arbitral award or commercial arbitral award, parties to an arbitration agreement may submit an arbitral award, an arbitration agreement and their translation in official language if documents are in another language in High Court for its implementation (1985).

The UNCITRAL Model 1985 has distinguished issue of setting aside an arbitral award and refusal of recognition and enforcement of an arbitral award but it has given almost same grounds for both matters. There are 6 grounds mentioned under article 34 of the UNCITRAL Model Law 1985 for setting aside an arbitral award and in article 36 same grounds are mentioned for refusal of recognition and enforcement an arbitral award except one ground that when arbitral award is set aside by the Court, it cannot be enforced (Ghouri, 2012).

The Arbitration Act 1940 does not deal with recognition and enforcement process of an arbitral award. The New York Convention 1958 is applicable in Pakistan under the Recognition and Enforcement Act Published by SCHOLINK INC. 
2011. Article 5 of the New York Convention 1958 states that the New York Convention 1958 does not stop an aggrieved party to avail any right under domestic legislation thus he may avail grounds of modification, remission and setting aside an arbitral award in Pakistan mentioned under sections 15, 16 and 30 of the Arbitration Act 1940.

Article 5 of the New York Convention 1958 and article 36 of the UNCITRAL Model Law 1985 state that recognition and enforcement of an arbitral award may be revoked (i) if parties to an arbitration agreement do not have capacity to enter into agreement of arbitration, (ii) if arbitration agreement is void, (iii) if subject matter of arbitration is not allowed to be arbitrated, (iv) if parties to arbitration agreement do not have notice of arbitration, (v) if arbitral tribunal is not established as agreed upon between contracting parties, (vi) if arbitral award is against public policy, (vii) if arbitral award is set aside by the Court $(1958,1985)$.

All parties to agreement of arbitration must have notice of submission. Right of notice is fundamental rule of due process which cannot be taken away from any party, if any party to arbitration agreement does not have notice of date, time and place of arbitration, he may challenge recognition and enforcement of an arbitral award. When an arbitral award is set aside by the Court, it will not have any force and liable to be rejected from enforcement as mentioned under article 5 of the New York Convention 1958 and under article 36 of the UNCITRAL Model Law 1985 (2013).

\section{Public Policy}

Recognition and enforcement of an arbitral award may be refused if it is not consistent with public policy. It is not clear yet what is public policy and what is its ambit. Modern Jurists have divided public policy into internal and external public policy. Internal public policy of every state is different from other state e.g. drinking alcohol and selling it prohibited in Pakistan because it is against internal public policy of Pakistan but in United States of America, drinking and selling alcoholic acid is not prohibited and it is not against public policy of United States of America (1787).

International Law Association suggested in London Conference 2000 and later recommended at New Delhi Conference 2002 that International Public Policy is consisted of (i) fundamental rules of natural law, (ii) principles of universal justice, (iii) Jus Cogens in public international law, (iv) general principles of morality (Audley, 2003).

Most case laws on public policy disclose that it has narrow scope and term public policy is applied in severe substantial and procedural situations of injustice. Supreme Court of India held in a case between Oil and Natural Gas Corporation Limited v Saw Pipes Limited that while recognizing and enforcing foreign arbitral awards, it is not mandatory to accept conservative interpretation of the concept. Public policy are those rules consisted of public, private, political, ethical and economic legal principles that are necessary for protection of society of societal model for nation at a given time $(2003,2011)$.

Public policy includes principles of natural justice, meaning: equal treatment of parties before decision maker. It also includes right of notice to parties which must be fulfilled and desired process of law must Published by SCHOLINK INC. 
be adopted by arbitrator in arbitration proceedings. High Court of Singapore held in a case between $V V$ $v V W$ that there is no need to distinguish between domestic arbitral award and foreign arbitral award while resolving issue of public policy (2008).

Public policy is not defined anywhere in Pakistani statute, this matter is ambiguous and needs clarification (Ullah, 2016). Pakistan is an Islamic country and its state religion is Islam as per article 2 of the Constitution of Pakistan 1973 and no law can be made in Pakistan which is against fundamental principles and injunctions of Islam as per article 227 of the Constitution of Pakistan 1973 (1973). In Islamic Law, public policy is consisted of five preservations, anything which affects these preservations would be considered an act against public policy, these preservations are (i) preservation of religion, (ii) preservation of life, (iii) preservation of intellect, (iv) preservation of progeny, (v) preservation of Life. These principles are reputedly mentioned in Holy Quran and Sunnah of Prophet Muhammad 选 and Imam Gazali mentioned these five principles all together in his book Ahya Uloom-ul-Din (Al-Ghazali, 1988).

\section{Conclusion and Recommendations}

Arbitration is one of the modes of Alternate Dispute Resolution. Alternate means proxy, dispute means issue and resolution is settlement of issue. Arbitration is settlement of civil dispute between contracting parties outside the Court by one or more arbitrators while avoiding technicalities of procedural law. Outcome of arbitration proceedings is an arbitral award which is required to be submitted for recognition and enforcement in Civil Court if arbitral award is domestic and in High Court if arbitral award is international. Presumption of correctness is attached with arbitral award and it cannot be disturbed merely on technical reasons. An aggrieved party to arbitration proceedings can apply before the Court for modification of an arbitral award in Pakistan under section 15 of the Arbitration Act 1940, for remission under section 16, for setting aside an arbitral award under section 30 of the Arbitration Act 1940 and for revocation of recognition and enforcement under article 5 of the New York Convention 1958 which is implemented in Pakistan under the Recognition and Enforcement Act 2011.

The Court or arbitral tribunal may modify an arbitral award on its own motion or on the request of aggrieved party to correct clerical mistake, remove unreferred things and remove an obvious error. Modification is only allowed if it does not affect essential part of an arbitral award and if the Court cannot modify arbitral award because there is a reasonable cause to believe that modification will affect its essential part, the Court would remit arbitral award to an arbitrator. As per Arbitration Act 1940, the Court would also remit an arbitral award if arbitrator left referred matters unsettled/unresolved or resolved matters not referred. The Court would set aside an arbitral award on application of aggrieved party, (i) if arbitrator misconducts himself, (ii) if arbitrator misconducts with arbitration proceedings, (iii) if arbitration proceedings superseding judicial proceedings, (iv) if an arbitral award come out after the Court declared arbitration proceedings void, (v) if an arbitral award is improperly procured, (vi) if an arbitral award is otherwise invalid.

Published by SCHOLINK INC. 
As per the New York Convention 1958 an aggrieved party may apply before the Court for revocation of recognition and enforcement of an arbitral award (i) if parties do not have capacity to enter arbitration agreement, (ii) if arbitration agreement is void, (iii) if parties to arbitration agreement do not have notice of arbitration proceedings, (iv) if subject matter of arbitration proceedings is not allowed to be arbitrated, (v) if arbitral tribunal not constituted as agreed upon between contracting parties, (vi) if an arbitral award is against public policy, (vii) if arbitral award is set aside by the Court.

Aggrieved party to arbitration proceedings is required to challenge an arbitral award in Pakistan within 30 days after submission of arbitral award before the Court as per article 158 of the Limitation Act 1908. Usually 90 days are given to an aggrieved party in all civil matters before the Court as per section 96 of the Code of Civil Procedure 1908. It is therefore recommended that article 158 of the Limitation Act 1908 should be amended and challenging time should be increased from 30 to 90 days. Articles 33 to 36 of the UNCITRAL Model 1985 and articles 50 to 55 of the ICSID Convention 1965 deal with modification, remission setting aside and annulment of recognition and enforcement of an arbitral award. Article 33 of the UNCTIRAL Model Law 1985 states that aggrieved party may request for correctness of an arbitral award within 30 days, thereupon, arbitral tribunal is required to correct an arbitral award or give interpretation of an arbitral award within 30 days or an additional award within 60 days. Articles 34 of UNCITRAL Model Law 1985 contains grounds of setting aside an arbitral award and same grounds are prescribed under article 36 for revocation of recognition and enforcement. Article 36 of the UNCITRAL of Model Law 1985 and article 5 of the New York Convention 1958 are same and applicable in Pakistan under the Recognition and Enforcement Act 2011 but grounds prescribed under article 34 of UNCTIRAL Model Law 1985 for setting aside an arbitral award not applicable in Pakistan.

Similarly, article 52 of ICSID Convention 1965 contains grounds of setting aside an arbitral award as it states that either party of arbitration proceedings may request annulment of an arbitral award by an application in writing within 120 days of its pronouncement (i) if arbitral tribunal was nor properly constituted, (ii) if arbitral tribunal exceeded from its powers, (iii) if members of arbitral tribunal involved in corruption, (iv) if there was a serious departure from fundamental rules of procedure (due process, fair trial, right of notice, right of hearing etc.), (v) if arbitral award has failed to state reasons. These grounds are not imbedded in Pakistani law hence an aggrieved party may not avail these grounds to set aside an arbitral award in Pakistan.

Pakistan has Dualism system, it requires an act of the Parliament to implement an International Statute at its soil, it is therefore highly recommended that Government of Pakistan should take steps to amend the Arbitration Act 1940 as per customs and usages of Pakistani society, under the light of International Conventions and injunction laid down in Holy Quran and Sunnah of Prophet Muhammad 䟠. 


\section{References}

Abdullah Contractors v Water and Power Development Authority. Yearly Law Report, 589: (Sindh High Court, 2006).

ADAMJEE Construction Company Limited v Islamic Republic of Pakistan. Pakistan. Law Digest, 180: (Sindh High Court, 2003).

Al-Abdullah Contractors Private Limited v Pakistan Water and Development Authority. Civil Law Digest, 798: (Sindh High Court, 2008).

Al-Ghazali, M. b. M. b. M. (1988). Ahya Uloom-ul-Din. Cairo, Egypt: Dar-ul-Afaq Al-Arabia.

Arbitration Act. (1940). Islamic Republic of Pakistan.

Audley, S. (2003). International Law Association Report on Public Policy as a Bar to Enforcement of International Arbitral Awards. Arbitration International, 19(2), 217-248.

Communication and Works Department v Messrs Design and Engineering System. Civil Law Digest, 1438: (Azad Kashmir High Court, 2013).

Constitution of Pakistan. (1973). Islamic Republic of Pakistan.

Contract Act. (1872). Islamic Republic of Pakistan.

Dallah Real Estate and Tourism Holding Company v Ministry of Religious Affairs. Government of Pakistan UKSC, 46: (Supreme Court of England, 2010).

Falcon Enterprises v National Refinery Limited. Civil Law Digest, 888: (Sindh High Court, 2006).

Ghouri, A. A. (2012). Law and Practice of Foreign Arbitration and Enforcement of Foreign Arbitral Awards in Pakistan. Springer Science \& Business Media.

Government of N.W.F.P. v Jan Construction Company Straightaway. Civil Law Digest, 502: (Peshawar High Court, 2012).

Hunter, J. M. H. (1985). The UNCITRAL Model Law. International Business Law, 13(399).

International Center for the Settlement of Investment Disputes Convention. (1965). World Bank Group.

IKerr, M. (1985). Arbitration and the Courts: The UNCTTRAL Model Law. International and Comparative Law Quarterly, 34(1), 1-24.

Maulana Abdul Haque Baloch v Government of Balochistan. Pakistan Law Digest, 641. (Supreme Court of Pakistan, 2013).

Muhammad Nadeem v Additional District Judge, BHAKKAR. Civil Law Digest, 441: ( Lahore High Court, 2012).

Mukhtar, S. (2016). Settlement of Disputes by Way of Arbitration in Pakistan. World Journal of Social Science Research, 3(4), 518.

Mukhtar, S., \& Mastoi, S. M. K. (2017) The Challenge of Arbitral Awards in Pakistan. Korean Journal of Commercial Arbitration, 27(1), 37-57.

National Highway Authority v MESSRS Hakas Private Limited. Pakistan Law Digest, 43: (Islamabad High Court, 2011).

New York Convention. (1958). United Nations.

Published by SCHOLINK INC. 
OGDCL v Marathon Construction Company. Civil Law Digest, 1483: (Azad Kashmir High Court, 2013).

Oil \& Natural Gas Corporation Ltd. v Saw Pipes Ltd. INSC, 236: (Supreme Court of India, 2003).

Phulchand Exports Ltd. v OOO Patriot. INSC, 1038: (Supreme Court of India, 2011).

Power Development Authority v MESSRS Ice Pak International Consulting Engineers of Pakistan.

Yearly Law Report, 2494: (Lahore High Court, 2003).

Qanun-e-Shahadat Order. (1984). Islamic Republic of Pakistan.

RAZO Private Limited v Pakistan Steel Mills Corporation Private Limited. Monthly Law Digest, 1399:

(Sindh High Court, 2009).

Redfern, A. (2004). Law and Practice of International Commercial Arbitration. London, United Kingdom: Sweet \& Maxwell.

S. M. I Brothers v Municipal Committee Murree. Civil Law Digest, 419: (Lahore High Court, 2003).

Sh. Muhammad Saleem v Ssaadat Enterprises. Civil Law Digest, 390: (Lahore High court, 2009).

Shackleton, S. R. (1997). The Applicable Law in International Arbitration Under the New English Arbitration Act 1996. Arbitration International, 13(4).

Syed Faqir Shah v Inayatullah Khan. Monthly Law Digest, 689: (Peshawar High Court, 2013).

Ullah, I. (2016). Public Policy in Arbitration: Still a Long Way to Go. Contemporary Asia Arbitration Journal, 9(1) 53-86.

UNCITRAL Model Law on International Commercial Arbitration. (1985). United Nations.

United States Constitution. (1787). United States of America.

VANOL Far East Marketing Private Limited v HIN Leong Trading Private Limited. CLOUT, 208: (Singapore High Court, 1996).

VV and Another v VW. 11: (Singapore High Court, 2008).

Won, S. -K. (2013). Overview of Alternate Dispute Resolution with Special Reference to Arbitration Laws in Pakistan. Journal of Arbitration Studies, 23, 149.

Zimbabwe Electricity Supply Commission v Genius Joel MAPOSA. CLOUT, 267: (Harare High Court, 1998). 